\title{
State of the art in rockfall - forest interactions
}

\author{
Luuk Dorren \\ Frédéric Berger \\ Martin Jonsson \\ Michael Krautblatter \\ Michael Mölk \\ Markus Stoffel \\ André Wehrli
}

\author{
Cemagref Grenoble (FR)* \\ Cemagref Grenoble (FR) \\ Swiss Federal Institute for Forest, Snow and Landscape Research $(\mathrm{CH})$ und BergByggKonsult $A B(\mathrm{SE})$ \\ Geography Department, University of Bonn (DE) \\ Geological Service, Austrian Torrent and Avalanche Control (AT) \\ Laboratory of Dendrogeomorphology, Department of Geosciences, University of Fribourg $(\mathrm{CH})$ \\ Federal Office for the Environment $(\mathrm{CH})$
}

\begin{abstract}
State of the art in rockfall - forest interactions
To effectively prevent rockfall related disasters below forested slopes, silvicultural, eco-engineering, civil engineering or mixed techniques can be used. To do this in a cost-efficient manner it is necessary to know the following: 1) where rockfall events occur and which magnitudes are likely, 2) to what extent the forest reduces the run-out distances, the jump heights and the energies of rocks falling downslope, and 3) how the protective function of forests could be improved. This paper gives an overview of the current scientific knowledge and methods that are applied by practitioners who deal with rockfall and forests protecting against it. Efficient ways to derive information on the probable magnitude and frequency of future rockfall events from the source and deposit area are described. Subsequently, the scientific knowledge on the energy absorption capacity of single trees and the currently available knowledge on the protective function of forest stands against rockfall are presented. Then easy-to-use tools and simulation models for rockfall hazard assessment on forested slopes are described. Finally, this paper identifies the most important challenges to be tackled in the field of integrated rockfall-forest research.
\end{abstract}

Keywords: rockfall, protection forests, review, Alps

doi: $10.3188 /$ szf.2007.0128

* 2 rue de la Papeterie, BP 76, F-38402 St. Martin d'Hères cedex, E-Mail luuk.dorren@cemagref.fr

$\mathrm{I}$ n March 2006, two children were killed in the French Alps by a falling rock of about $0.3 \mathrm{~m}^{3}$ that impacted a family car. Luckily, such accidents are rare. Rockfall events, however, occur frequently in mountainous areas (Gardner 1970, DussaugePeisser et al 2002, Hantz et al 2003, Sass 2005). At locations where rockfall is known to pose risks to people, housing or infrastructure, protective structures have usually been put into place. In many of those cases, rockfall nets and dams are constructed upslope from houses, roads or railways (e.g., Peila et al 1998, Gerber 2001). In situations where the area between the element at risk and the cliff face is covered with mature forest, the risk is somewhat hidden. In such cases, the risk posed by rockfall is generally known only if rockfall events have reached houses or roads in the past. To effectively prevent rockfall related disasters below forested slopes, silvicultural, eco-engineering, civil engineering or mixed techniques can be used (Dorren et al 2005). Here, eco-engineering is defined as the utilisation or enhancement of biological processes in or together with engineering design. Historically, forests were relied upon for protection but with improvements in engineered materials and design there was a move toward engineered works, but these structures have generally had a shorter lifespan than originally planned.

To protect against rockfall in a cost-efficient manner it is necessary to know: 1) where and what magnitude rockfall events occur, 2) to what extent the forest may reduce the run-out distances, the jump heights and the energies of rocks falling downslope, and 3) how the protective function of forests could be improved.

Research on rockfall mechanics has been carried out since the 1920's (Smekal 1920, Lehmann 1933, Bakker \& le Heux 1946, Crandell \& Fahnestock 1964, Kent 1966, Broilli 1974, Bozzolo \& Pamini 1986, Giani 1992, Azzoni \& de Freitas 1995, Erismann \& Abele 2001, Chau et al 2002). In contrast, research on the interactions between rockfall and forests was only initiated in the 1980's (Couvreur 1982, Jahn 1988). Currently, significant progress has been made in various aspects related to interactions between falling rocks and forests. The objective of this paper is to present an overview of the current scientific knowledge and methods that are used by practitioners who deal with rockfall and forests protecting against it. Finally, this paper identifies the 


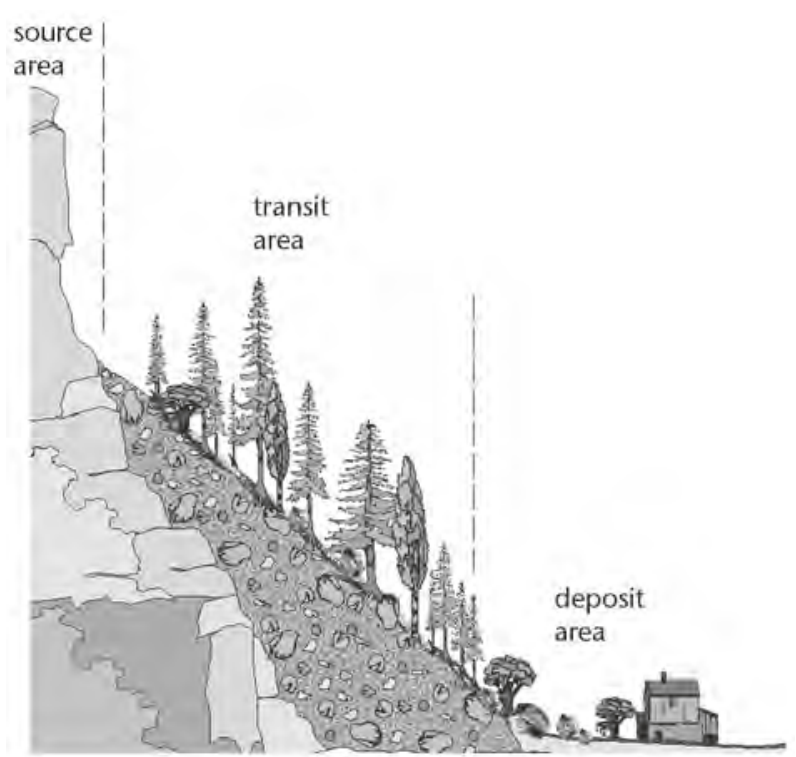

Fig 1 Generalisation of the three main areas on an active (forested) rockfall slope.

most important challenges that need to be met in order to improve the protection against rockfall using the natural mitigation potential of forests.

The structure of the first part of this paper follows principally the three main areas that can be distinguished on an active rockfall slope: 1) the source area, 2) the transit area, and 3) the deposit area (Figure 1). Hazardous rockfall source areas are typically characterised by steep rock faces that have unfavourable combinations of slope aspect and the dip and strike of bedding planes and the most prominent joint sets. The transit area lies between the rockfall source area and the deposit area. In this area, the rockfall velocities as well as the jump heights are maximal. Logically, the deposit area is the area where (most) rocks stop. These areas could overlap each other and boundaries between them are therefore not strict.

In all three areas, information can be obtained about the probable magnitude of future rockfall events. This is an extremely important parameter when dealing with rockfall protection. Therefore, this article pays considerable attention to the available methods in the three areas for determining the rockfall magnitude as well as the rockfall frequency. For each area we discuss the role of forests regarding rockfall protection. In the section dealing with the transit and deposit area this is done separately for individual trees and for forest stands as a whole. The subsequent sections outline management guidelines, criteria and indicators for optimal rockfall protection forests, and tools for assessing the protective function of forests against rockfall. The final section identifies challenges in integrated rockfall forest research.

\section{Rockfall source area}

In this article, we define rockfall as a relatively small landslide confined to the removal of individual rocks generally smaller than $5 \mathrm{~m}^{3}$ from a cliff face, but singular rocks with larger volumes (e.g., $10 \mathrm{~m}^{3}$ ) should not be excluded. In addition, we do not differentiate between sizes of rocks, as there are many systems to define sizes of loose rocky material. For example, the system that differentiates between cobbles $(\varnothing=64-256 \mathrm{~mm})$ and boulders ( $>256 \mathrm{~mm}$ ), as described by Wentworth (1922) and later adapted by others (e.g., Blair \& McPherson 1999). Another system differentiates between rocks $(\varnothing<50 \mathrm{~cm})$ and blocks ( $\varnothing 250 \mathrm{~cm})$, as mentioned by Gerber (2001). Following the volumetric classification of Whalley (1984), the term rockfall in this paper refers mainly to debris fall $\left(<10 \mathrm{~m}^{3}\right)$, but also to boulder fall $\left(10-100 \mathrm{~m}^{3}\right)$.

\section{Locating active rockfall slopes}

At the cliff face, being a potential source area for rockfalls, often a lot of information about the potential rockfall hazard can be found. The two types of parameters that can be assessed are so-called «rockfall promoters» and «rockfall triggers». Rockfall promoters are joint attitude, presence of joint infillings, open cracks, and rock strength. These parameters determine the preparation of loose rocks that eventually could fall down. Rockfall triggers are joint water pressures, freeze-thaw mechanisms, tree root growth and earthquakes, which initiate the actual rockfall (Dorren 2003, Krautblatter \& Dikau 2007). Due to the complex interaction of rockfall promoters and triggers, it is difficult to provide the failure probability of a potentially falling rock as a function of a given period (Hantz et al 2003).

Quite often rockfalls occur suddenly in places with few or no prior indications of instability. Slope instability indicators include both features related to future failure, such as open cracks or rocks in limited equilibrium, and features indicating recent and past failures, such as scars in the cliff face. Generally, past rockfall activity is a good source of information if rockfall conditions in terms of magnitude and frequency of rockfall promoters and rockfall triggers have not changed significantly. Recent rockfall activity in the source areas is apparent due to the presence of «fresh» scarps, whose age can be judged according to the degree of weathering.

Future rockfall activity can be detected by comparing the geological structure of the rock mass and the topography of the slope (Hoek \& Bray 1981, Goodman \& Shi 1985). In this context, the size, density, orientation and continuity of rock discontinuities are of central importance. Methods for the quantitative description of discontinuities in rock masses are summarized by Barton (1978). Many 
methods currently exist for estimating the probability of failure that are based on relative rock failure rating systems (Mazzoccola \& Hudson 1996, Budetta, 2004, Corominas et al 2005, Jaboyedoff et al 2005). Frequently applied systems are the Slope Mass Rating by Romana (1988), the Rockfall Hazard Rating System (RHRS) developed by Pierson et al (1990) and Matterrock (Rouiller et al 1997). Such methods generally require ratings for geologic characteristics, the volume of the potentially falling rock, rockfall history, triggering factors (climate, water circulation), and in some cases estimates for future trends in the stability of a slope.

\section{Assessing rock size}

The volume of a detachable block may be estimated, as a first approximation, on the cliff face. Three parameters are considered as the most important when determining the volume of a detachable block: spacing, attitude, and persistence of discontinuities (Corominas et al 2005). Spacing of discontinuities controls the size of the individual blocks after the first impact of the fallen mass on the ground (Priest \& Hudson 1976). Attitude and persistence (continuity) of joints determines the size of the largest detachable block. It is usually difficult to measure rock sizes in the rockfall source area because of limited accessibility as well as the imminent danger of rockfall. In addition, there are methodological limitations for determining joints that will finally lead to rock detachment. However, it is important to analyse both the source area and the deposit area to gain an indication of the rock size distribution (Mölk 2000). Available methods for assessing the rock size in the source area are summarised in Table 1.

\section{Assessing rockfall frequency}

In general, the frequency of rockfall events has to be assessed separately for all rock size classes as no frequency - magnitude relations have been established that covers all rock size classes (Abele 1972, Whalley 1984, Krautblatter et al 2007). Important sources for predicting rockfall frequencies are historical and present observations. Larger rockfall events are often recorded in historical descriptions, documents and maps (Morche et al 2006), but their interpretation could require experience with historical sources (Glade \& Lang 2003). The prediction of future frequencies on the basis of historical rockfall events is, however, only possible if unaltered environmental conditions can be assumed (Krautblatter \& Moser 2006). Therefore, such methods are generally not applicable for environments that 1) currently experience a phase transition due to climatic fluctuations (e.g., permafrost melting), 2) whose constitutional state has been altered by a preceding major event (e.g., large rockfall), 3) whose environmental setting has been changed due to anthropogenic or natural interactions (e.g., road undercutting or fluvial incision), and 4) those which are prone to be affected by future triggering situations (e.g., earthquakes, extreme rainstorm events).

For recent rockfall frequencies, institutionally organised assessments of rockfall activity are in some cases made by geological services, organisations surveying or constructing infrastructure, forest or natural hazard management services or by scientific organisations (Hungr \& Evans 1988). As those surveys are not widely available, observations of local inhabitants and authorities are crucial for referring recent rockfall deposits to a certain time of collapse.

\begin{tabular}{|c|c|c|c|}
\hline Method & Description & Advantage & Disadvantage \\
\hline Visual estimation & $\begin{array}{l}\text { Estimating the volumes of the } \\
\text { joint-bordered rock-bodies } \\
\text { visually. }\end{array}$ & Rapid method. & $\begin{array}{l}\text { Unreliable, difficult to reproduce, } \\
\text { dependent on personal experience. }\end{array}$ \\
\hline $\begin{array}{l}\text { Measurement of } \\
\text { rock size (three axes) } \\
\text { by measuring tape }\end{array}$ & $\begin{array}{l}\text { Measurement of joint borde- } \\
\text { red rock-bodies by measuring } \\
\text { tape on the rock-face. }\end{array}$ & Rock shape also captured. & $\begin{array}{l}\text { Often not applicable due to difficult } \\
\text { accessibility very time-consuming to } \\
\text { assess a statistically reliable sample. }\end{array}$ \\
\hline
\end{tabular}

Tab 1 Methods for assessing rock size in a rockfall source area. 

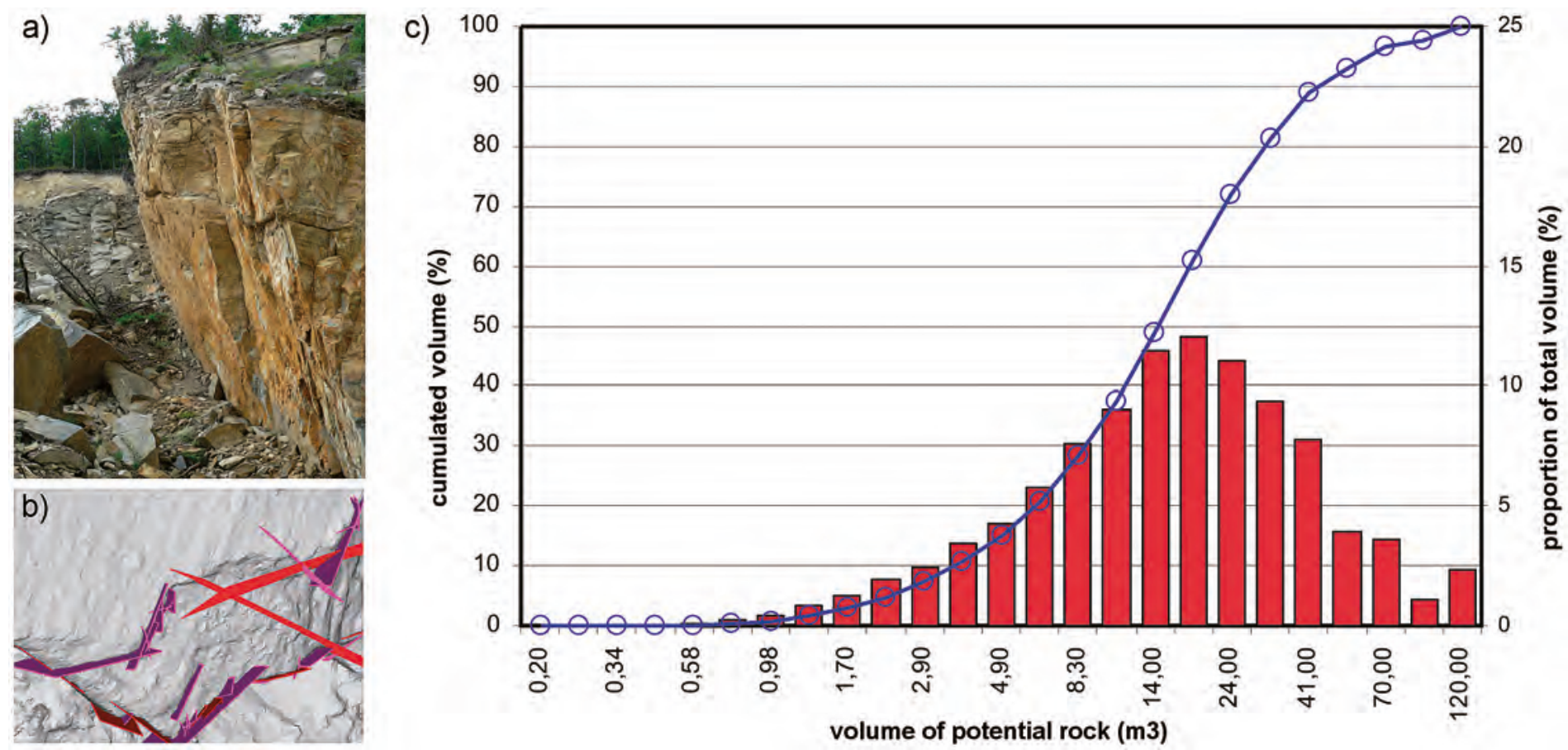

Fig 2 Left side: photo of the demonstration site. Right side: result of the rock size analysis by using terrestrial laser scanning. (Photo: Manfred Scheikl).

\section{Effects of trees}

In the rockfall source or detachment area, effects of trees regarding rockfall protection are generally negative. Roots of large trees can promote rockfall activity, because they generally penetrate existing joints and bedding planes in the bedrock and act as wedges. Movement of the tree stem due to snow or wind forces can cause rockfall via an additional wedge effect of the roots (Gerber 1998). In addition, the presence of roots in the bedrock accelerates chemical weathering (Jahn 1988). Therefore, in practice, unstable trees on top of cliffs and trees with large roots penetrating the bedrock should be removed. If the above described negative effects of trees are absent, the positive effect is that stable standing trees act as barriers and decelerate or stop falling rocks, even in steep source areas.

\section{Transit and deposit area - rockfall frequency and magnitude}

The easiest indicator for assessing the location of active rockfall slopes is the presence of rockfall deposits in the form of a talus slope or singular rocks deposited below a cliff face. A talus slope, also called scree slope, is a sloping mass of coarse rock fragments accumulated at the foot of a cliff or slope (Allaby \& Allaby 1990). Of note, a deposit area can also act as a secondary rockfall source area.

Talus slopes document the activity of rockfall source areas over a certain span of time, e.g., a Lateglacial/Holocene (10000-15000 years) time period in Alpine environments. Therefore, they witness the historical rockfall activity. The present degree of rockfall activity is indicated by vegetation cover on talus slopes. Where rockfall is the main restricting factor for plant growth, non-vegetated talus slopes match with high rockfall activity, whereas talus slopes tend to be vegetated or even forested with decreasing rockfall activity (Gerber 1974). In situations where the slope is forested, rocks stopped by trees below a cliff face and visible rock impacts on tree stems are also good indicators of active rockfall slopes.

\section{Assessing rock size}

Deposit areas represent fragments of ancient and recent rockfall events and are therefore good sources for evaluating rock sizes. A prerequisite for assessing rock sizes on talus slopes is that rockfall conditions in terms of lithology and/or fracturing degree in the rockfall source area have not changed significantly since the initial build-up of the talus slope. Methods to assess the rock size distribution in the deposit area are summarised in Table 2.

When examining deposit areas, and especially talus slopes, it is necessary to recognise that the distribution of rock sizes is not homogeneous. Large rocks travel further (Kirkby \& Staham 1975, Erismann \& Abele 2001, Meissl 2001, Dorren, 2003) and are therefore concentrated at, or deposited beyond, the base of the talus slope. Secondly, over time, large rocks that are deposited on the talus slope can be covered by fine debris (small rocks). The most efficient way of finding buried rocks is ground penetrating radar (GPR) (Sass \& Krautblatter 2007). Thirdly, it is necessary to recognise that the size of 

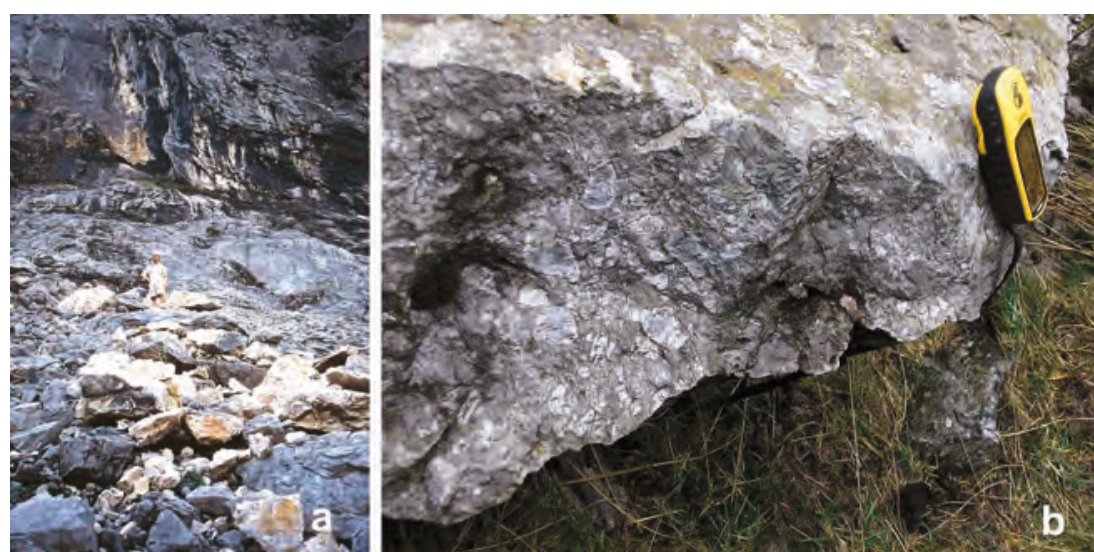

Fig 3 a) Freshly detached surfaces carbonate rocks (Wetterstein limestone) can easily be distinguished optically (Reintal, Bavarian Alps). b) The freshly detached surface of a siliceous volcanic agglomerate with $\mathrm{cm}$-large white inclusions is more difficult to see. The top side on the photo was exposed to weathering prior to the rockfall (Cwm Idwal, Snowdonia, North Wales).

a deposited rock may not always correspond to the original size of the falling rock, due to fracturing during downslope movement. Surfaces that have been freshly exposed due to fracturing are often visually apparent due to different weathering intensity and the lack of a biocrust, i.e., a cover with a film of bacteria (Sass et al). ${ }^{1}$

\footnotetext{
1 Sass O, Krautblatter M, Viles HA (2007) Quantifying and comparing present-day and long-term Holocene rockwall retreat rates in Nant Ffrancon, Snowdonia, North Wales. Earth Surf Proc Land (submitted).
}

\section{Assessing rockfall frequency}

If no information on the timing of the rockfall is available, a range of relative and absolute dating techniques can be utilised. Within the relative dating techniques, one of the cheapest possibilities is comparing the degree of weathering of the side of the rock that was formerly attached to the rock cliff to that which was exposed to weathering prior to the rockfall. For carbonate rocks, unweathered surfaces are often white or yellow and turn grey after some years of surface exposure (e.g. 5 years for finegrained limestones according to Friedel 1935). For non-carbonate rocks the difference in degree of weathering is less obvious, but nevertheless apparent (Figure 3). Another indication of freshly exposed surfaces is the absence of green biocrusts. An easy measurement of the degree of weathering can be done with a Schmidt Hammer (Sass et al submitted). If needed, thin sections of weathering crusts can give final evidence for differential weathering (Trudgill \& Viles 1998, Taylor \& Viles 2000).

A known and suitable absolute dating technique is lichenometric dating. It is based on the assumption that the concentric growth of lichens on rocks provides an indication of the time since the rockfall event. Lichenometric dating is possible due to the regular growth rate of some species of lichen (Bull \& Brandon 1998, McCarroll et al 1998, BajgierKowalska 2002). Lichenometric dating is primarily applied to non-carbonate rocks, and only few stud-

\begin{tabular}{|c|c|c|c|}
\hline Method & Description & Advantage & Disadvantage \\
\hline $\begin{array}{l}\text { Random estimation } \\
\text { of block sizes }\end{array}$ & $\begin{array}{l}\text { Subjective estimation of block sizes } \\
\text { without measuring anything. }\end{array}$ & Quick and cheap. & $\begin{array}{l}\text { Results are very subjective and } \\
\text { unreliable, not reproducible. }\end{array}$ \\
\hline $\begin{array}{l}\text { Random tape } \\
\text { measurement of the } \\
\text { three axes of the rocks } \\
\text { of a random sample }\end{array}$ & $\begin{array}{l}\text { Wandering around at the deposit area } \\
\text { and measuring block-axes randomly. }\end{array}$ & Rock form also captured. & $\begin{array}{l}\text { Results very likely not reproducible } \\
\text { due to random selection of measured } \\
\text { blocks. }\end{array}$ \\
\hline Scan-line-method & $\begin{array}{l}\text { Measurement of the mean diameter of } \\
\text { all rocks touched by a rope/measuring } \\
\text { tape in the falling line of the slope, mi- } \\
\text { nimum sample } 150 \text { rocks (Fehr 1987). }\end{array}$ & $\begin{array}{l}\text { Rather fast, covering the sorting ef- } \\
\text { fect of deposition area (downward } \\
\text { coarsening), reproducible, statisti- } \\
\text { cally validated. }\end{array}$ & $\begin{array}{l}\text { Simplification of block geometry } \\
\text { and -size due to measurement of mean } \\
\text { diameter. }\end{array}$ \\
\hline $\begin{array}{l}\text { Area-counting } \\
\text { procedure }\end{array}$ & $\begin{array}{l}\text { Measurement of the mean diameter } \\
\text { of all rocks within a distinct rectangle } \\
\text { or circle on the slope. }\end{array}$ & Reproducible, statistically validated. & $\begin{array}{l}\text { Time-consuming, Simplification of } \\
\text { block geometry and -size due to } \\
\text { measurement of mean diameter. }\end{array}$ \\
\hline Sieving & $\begin{array}{l}\text { Taking a representative sample and } \\
\text { sieving it in laboratory. }\end{array}$ & $\begin{array}{l}\text { Reproducible results, given a correct } \\
\text { sampling procedure statistically vali- } \\
\text { dated, standard procedure in sedi- } \\
\text { mentology (laboratories mostly } \\
\text { available). }\end{array}$ & $\begin{array}{l}\text { Due to the mostly huge sample size } \\
\text { required to get representative results, } \\
\text { this method is very rarely applicable. }\end{array}$ \\
\hline Fotosieving & $\begin{array}{l}\text { By taking a photograph of a represen- } \\
\text { tative section of the scree slope, the } \\
\text { rock size distribution can be determi- } \\
\text { ned semi automatically by support of } \\
\text { various software (e.g., GRA-frac, } \\
\text { Scheikl 2006). }\end{array}$ & $\begin{array}{l}\text { Quick, reproducible results, statisti- } \\
\text { cally validated. }\end{array}$ & $\begin{array}{l}\text { Often the scree material is covered } \\
\text { with soil/vegetation and therefore only } \\
\text { single rocks from recent events are ac- } \\
\text { cessible for measurement. Modern soft- } \\
\text { ware not commercially available. }\end{array}$ \\
\hline
\end{tabular}

Tab 2 Methods for assessing the rock size distribution in the deposit area. 
ies have succeeded in dating lichens on carbonate rocks. Growth curves of lichens must be calibrated using local inventories such as gravestones (Winchester \& Chaujar 2002).

If funding is available, sophisticated absolute dating methods of deposited rocks can be applied. An overview of possible methods for dating rockfall events is given by Lang et al (1999). Frequently applied methods include dating of underlying and covering sediments using carbon content for ${ }^{14} \mathrm{C}$-datings, or using quartz and feldspar content for luminescence dating (Schrott et al 2002). A newly introduced method is the dating of the surface exposure of rocks with cosmogenic nuclides. Surface exposure dating is possible using ${ }^{10} \mathrm{Be}$ for siliceous rocks (Ballantyne \& Stone 2004) and ${ }^{36} \mathrm{Cl}$ for carbonate rocks (Desilets et al 2006). However, as the application of these methods is still very expensive, they are mostly carried out for scientific investigations. All these methods have their limitations; for example, ${ }^{14} \mathrm{C}$-datings are generally not used for any material that is less than at least 50 years old. Moreover, there are confidence intervals that do not allow an exact date to be determined.

Another absolute dating technique is dendrogeomorphology, which studies «signatures» left in tree-ring sequences after geomorphological processes (e.g., tangential rows of traumatic resin ducts, callus overgrowing rockfall scars, reaction wood forming after tilting of the stem, sudden growth reduction as a result of breakage of the tree top). Dendrogeomorphology uses information on scars that are still visible, as well as overgrown scars that are hidden in the tree (Figure 4).

Over the last few years, dendrogeomorphology has been increasingly used in Switzerland to study past rockfall activity (Stoffel 2006, Stoffel \& Perret 2006). Such studies provided reliable reconstructions of rockfall activity covering several centuries (Stoffel et al 2005a). The identification of the

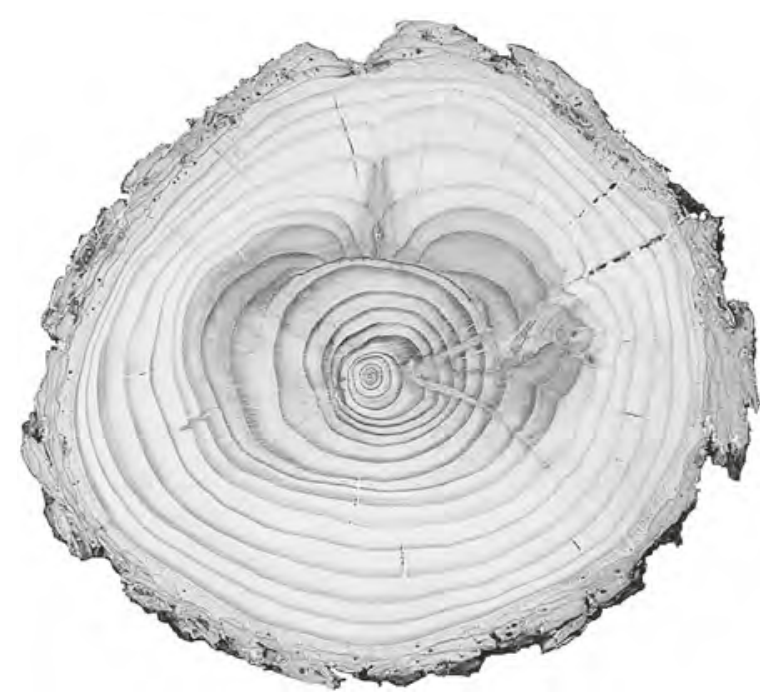

Fig 4 Rockfall scar on a cross-section of Larix decidua Mill. intra-annual position of scars together with data on the vegetation growth period even allowed determination of past rockfall activity with monthly resolution (Stoffel et al 2005b, Perret et al 2006). Dendrogeomorphology uses information on scars that are still visible, as well as overgrown scars that are hidden in the tree. For a rapid assessment of the rockfall frequencies during recent years $(<20$ years depending on the size of the original scars), only the visible scars can be used (of note: the sample in Figure 4 has closed over in 5 years). For a more detailed investigation of rockfall frequencies over the several decades to centuries, a labour intensive fieldwork is required.

\section{Effects of forest in the transit and deposit area}

In both the transit and the deposit areas, a protection forest stand is generally more effective in reducing the velocity and the rebound heights of falling rocks than in the source area, because the slopes are generally less steep and the forests more dense. As mentioned before, trees do have a barrier effect in the source area as well. Therefore, the following section finds its application mostly in the transit and deposit areas, but is not restricted to those two.

\section{Energy absorption by single trees}

It is often thought that only rocks with a maximum volume of approximately $2 \mathrm{~m}^{3}$ can be stopped by single trees. There are many examples throughout the Alps of large rocks, up to $10 \mathrm{~m}^{3}$, being stopped by trees. However, the probability that trees will be completely destroyed if impacted by such rocks is higher.

A single tree dissipates energy during a rock impact in several different ways: rotation and translation of the root system, deformation and oscillation of the tree stem, and local penetration of the rock at the impact location (Foetzki et al 2004, Brauner et al 2005). Because a single tree absorbs energy in different ways, quantification of the total amount of absorbed energy has proven to be very difficult. To quantify the energy absorption capacity, both simplified theoretical methods and results from full-scale experiments can be used. Three theoretical methods exist. The method suggested by Stokes et al (2005) uses data from static winching experiments to calculate the amount of energy required to cause a failure in the root system. The method suggested by Brauner et al (2005) assumes that the bending energy is fully developed in the whole tree stem due to the oscillation of the tree stem. This is justified by the observation that the treetops break due to a rock impact to the lower stem. 
The simplest method is the one suggested by Couvreur (1982) and Zinggeler (1990), where values for the fracture energy are derived from standardized dynamic impact tests on small knot-free samples. However, recent investigations on green fresh tree stems from Norway spruce (Picea abies L. Karst.) trees have shown that the fracture energy per unit area increases by a factor 5 compared to small knot-free samples (Ammann 2006).

None of the theoretical methods described take into account the dynamic effects of the whole tree stem, the root-soil plate, and the surrounding soil. Therefore, real-size rockfall experiments were carried out on living trees to obtain reasonable values for the energy absorption capacity. These were performed on a forested (predominantly Abies alba) slope in the French Alps (Dorren \& Berger 2006) and on a forested (predominantly Picea abies) slope in the Swiss Alps (Kalberer et al 2007). Both of these experiments are briefly discussed below.

For the experiments in the French Alps, large individual spherical rocks were released on a $38^{\circ}$ slope and the velocity of the rocks was derived from digital video films (Dorren \& Berger 2006). The translational kinetic energy was calculated before and after a tree impact that led to stem breakage, which made it possible to determine the amount of energy absorbed by the tree. On the basis of their experiments, Dorren \& Berger (2006) proposed an exponential relationship between the amount of energy that can be dissipated by an Abies alba tree and the diameter at breast height (DBH, measured at a height of $1.3 \mathrm{~m}$ upslope of the tree stem). By using a scaling factor, based on previously published fracture energies, they obtained a relationship between the energy absorption capacity and the DBH for different tree species (Figure 5). They also established a relationship between the energy absorption capacity of a single tree and the degree of eccentricity of the rockfall impact on the tree stem (Figure 6). These tests and their results have been extensively reported by Dorren \& Berger (2006).

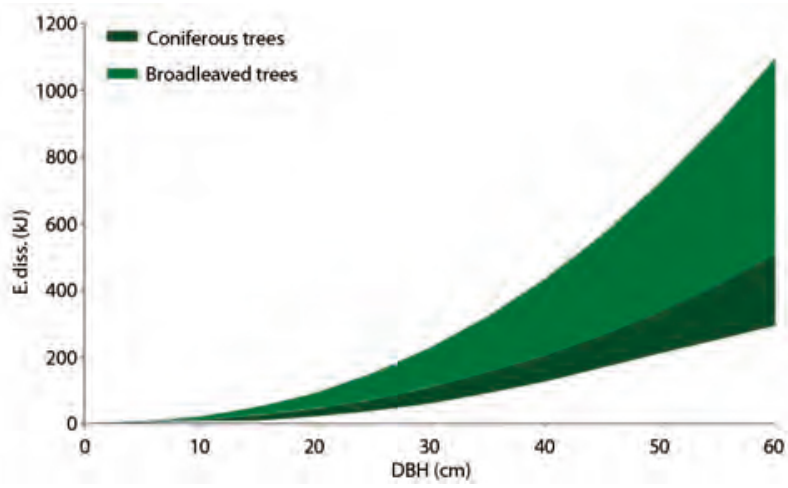

Fig 5 General relationship between the diameter at breast height $(D B H)$ and the range of energy that can be dissipated during a rockfall impact lower than $2 \mathrm{~m}$ on the tree stem for broad-leaved and coniferous species (based on data from Dorren \& Berger 2006).

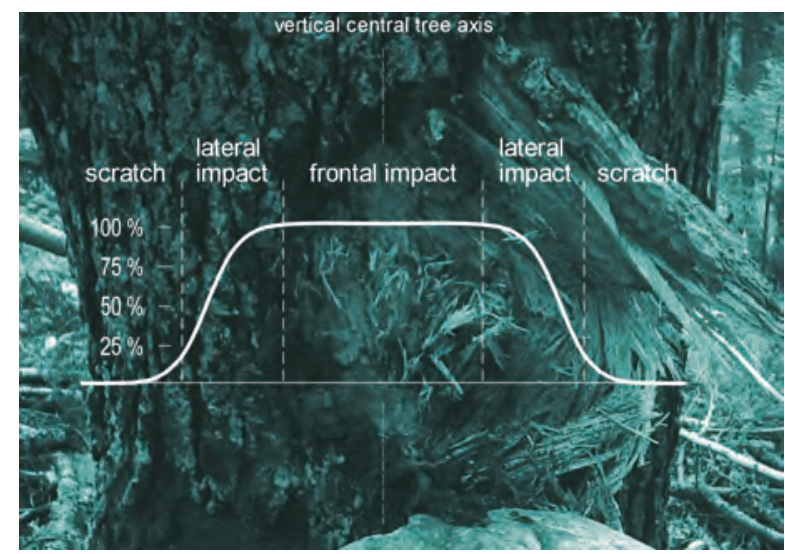

Fig 6 Sigmoidal relationship between the horizontal position of the impact centre on the tree stem and the fraction of energy that can be dissipated by a tree (modified from Dorren \& Berger 2006).

In the Swiss Alps, the complex interaction between a rock and a tree during an impact has been investigated with a guided trolley that impacts the tree stem frontally (Kalberer et al 2007). During the impact, the response of the tree was monitored using accelerometers and high-speed cameras. Because of the accurate monitoring of the tree displacement during the rock impact, it was possible to describe where and how much energy was absorbed in the tree stem and the root-soil plate. It was observed that different processes such as stem bending, rotation, and translation of the root-soil plate absorbed the initial energy of the trolley. During these experiments it was found that a major portion of the initially absorbed energy was absorbed by the root-soil system during the rotation and translation of the root-soil plate.

When comparing the maximum energy that can be dissipated by a single Norway spruce tree with a DBH of $0.45 \mathrm{~m}$ as obtained by: 1) standardized dynamic impact tests on small knot free samples (used fracture energy $=5 \mathrm{~J} / \mathrm{cm}^{2}$ ), 2) static winching experiments, 3) bending energy, and 4) real size rockfall experiments, method 4 is identified as providing the highest values (Table 3 ).

\section{Protective effects at the forest stand level}

If the size of the dominating falling rocks as well as the rockfall frequency is known, an evaluation can be made whether an existing forest has a significant mitigation role to play or whether the chance exists that it will be destroyed by future rockfall events. Whereas rock shape is thought to have a certain influence on the rockfall process on forested slopes (Frehner et al 2005), rock size is generally the most important factor for determining the potential protective effect of a stand. It is well known that rock avalanches destroy forests that cover the transit and deposit area. Individual rocks, however, 


\begin{tabular}{|l|r|}
\hline Method & $\begin{array}{l}\text { dissipated } \\
\text { energy (kJ) }\end{array}$ \\
\hline 1) standardized dynamic impact tests \\
on small knot free wood samples
\end{tabular}

Tab 3 Maximum energy that can be dissipated by a Picea abies tree with a DBH of $0.45 \mathrm{~m}$ as obtained by different methods.

can be effectively stopped by forests. This includes rocks with large volumes (Figure 7), as shown by examples from the French Southern Alps (Berger \& Dorren 2007).

Rickli et al (2004) estimate that an effective mitigation of rockfall hazard by a forest stand is limited to a rock mass of approximately $10000 \mathrm{~kg}$ and a velocity of approximately $20 \mathrm{~m} / \mathrm{s}$. Whereas there is no doubt that such an upper limit (i.e. a maximum rock size) exists, the values given by Rickli et al (2004) do not necessarily represent absolute limits.

Stands with high stem densities are considered to be very effective in stopping falling rocks (Omura \& Marumo 1988, Cattiau et al 1995). However, uneven multilayered stands with a mosaic of all sizes and age classes are considered more suitable as regeneration is better ensured in such stands (Dorren et al 2004, O'Hara 2006).

For small rocks, stand density rather than DBH is important, since many trees are required to increase the probability of impact (Jahn 1988, Dorren et al 2005, Wehrli et al 2006). In general, the larger the moving rock, the larger the mean DBH required to stop movement. However, the required DBH to stop

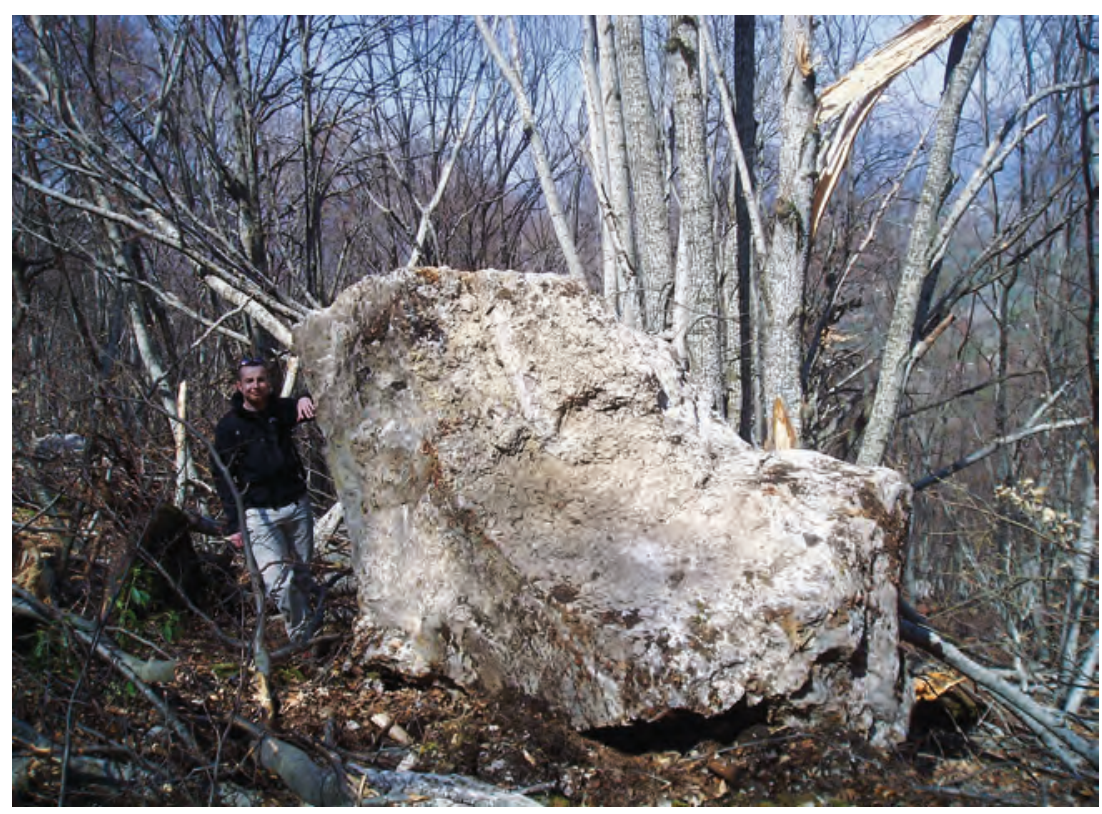

Fig 7 Rock with an estimated volume of $7 \mathrm{~m}^{3}$ stopped in a forest near Serres in the Southern French Alps. a falling rock depends on the tree species, because, in general, broad-leaved trees are more resistant against rockfall impacts than coniferous trees (Dorren et al 2005, Stokes et al 2005, see also Figure 5).

As a rule of thumb, Schwitter (1998) suggested that the mean DBH of trees in a stand should be approximately one-third of the decisive size of the falling rocks. This rule of thumb has been confirmed by the findings of Dorren et al (2005). Further, they found that the forest cover reduced the rockfall velocities on average by $26 \%$ and the maximum rebound heights by $75 \%$. Their results confirm the findings of Jahn (1988) and Doche (1997), who conducted rockfall experiments on forested slopes. They concluded that rockfall velocities on a forested slope with a mean gradient between 33 and 40 degrees are between 15 and $25 \mathrm{~m} / \mathrm{s}$ and that bounce heights are generally between 1 and $2 \mathrm{~m}$. Other field research on rockfall in forests has been done by Couvreur (1982), Zinggeler (1990), Gsteiger (1993), Cattiau et al (1995), Perret et al (2004), and Stokes et al (2005), who mainly undertook retrospective analyses of rockfall trajectories on forested slopes. They found similar velocities and rebound heights. Tree impacts also cause lateral deviations in the rockfall trajectory. As a result, the total travelling distance of a moving rock is generally longer on forested slopes (Dorren et al 2005). As a result, the chance of the rock impacting a tree increases. However, it also results in a wider run-out area (Figure 8). A lateral deviation of $10^{\circ}$ from the central downslope line to both sides was observed by Dorren et al (2005) and Jahn (1988).

\section{Tools for assessing the protective function of forests}

The available tools for assessing or quantifying the protective function of forests against rockfall can be grouped into either 1) rapid assessment tools or 2) simulation models. Many of these tools can also be used for rockfall hazard mapping, taking the role of forests into account, or for mapping forests that currently provide effective protection against rockfall.

\section{Rapid assessment tools}

One of the first rapid assessment tools was the Mean Tree Free Distance (MTFD) calculation by Gsteiger (1993), later adapted by Perret et al (2004) and Dorren et al (2005). The MTFD basically calculates the probable mean distance between two tree impacts in a forest stand, where the forest structure is considered as a regular grid. Brauner et al (2005) also developed a tool that is based on the MTFD concept. Moreover, they added a calculation of the energy that would potentially be dissipated per tree 
Fig 8 Tree impacts lead to lateral deviation of falling rocks. As a result, the run-out area generally equals an area covering $10^{\circ}$ both sides from the steepest downslope direction.

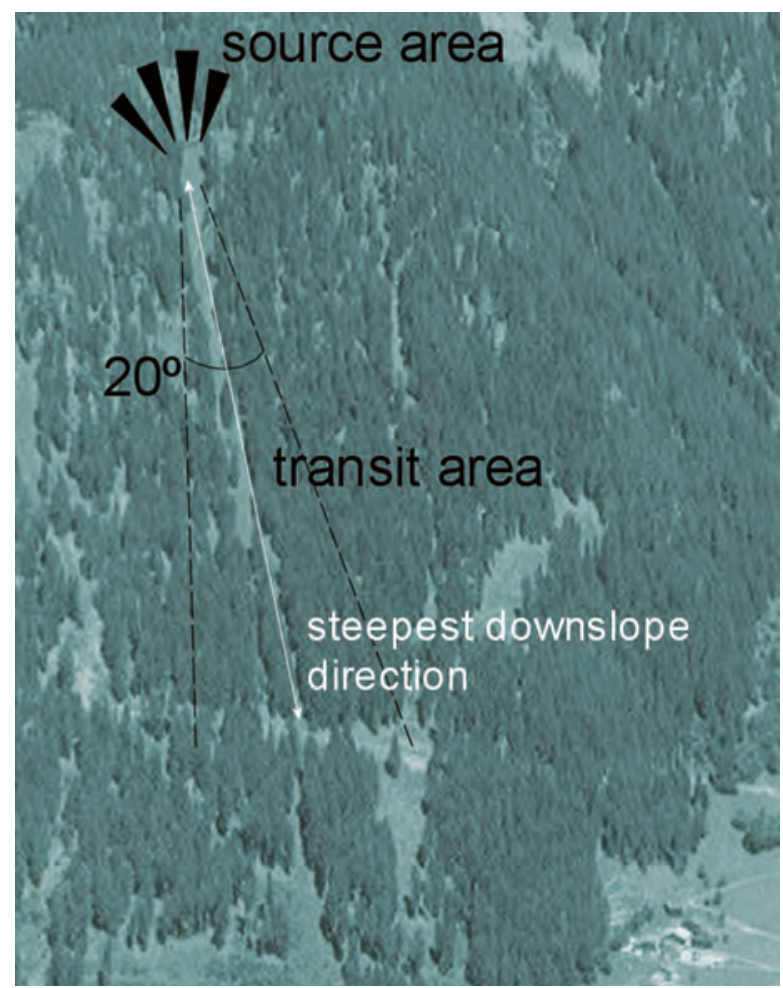

impact. The latter was based on the fracture energy per unit volume wood, which was derived from laboratory bending tests of whole stems.

Another tool that combines the number of probable impacts in a forest stand with the energy dissipative capacity of trees is Rockfor.net (Berger \& Dorren 2007). This tool allows a site-specific assessment of the current protective effect of a stand while taking into account forest, terrain, and rock characteristics. The basic idea of the rapid assessment tools is that a forest manager can easily assess the protective capacity of a forest stand to support decision making on required silvicultural or technical measures.

\section{Simulation models}

There is a plethora of rockfall simulation models, varying from $2 \mathrm{D}$ to $3 \mathrm{D}$ and from statistical models to deterministic models. With the increasing digital mapping and spatial modelling capabilities, there is a tendency towards 3D combined deterministic - probabilistic rockfall simulation models, both at local and regional scale (for overviews see Guzetti et al 2002, Dorren et al 2006). However, only a few rockfall simulation models take into account the mitigating effect of the existing forest cover (e.g., Zinggeler 1990, Cattiau et al 1995, Liniger 2000, Dorren \& Seijmonsbergen 2003, Le Hir 2005, Dorren et al 2006, Stoffel et al 2006).

Rockfall simulation models that explicitly account for forests, include the spatial distribution of different forest stands, DBH distributions and species, assist in determining optimal combinations and locations of technical and silvicultural mea- sures for a given site. Furthermore, they enable rockfall hazard zoning with and without taking into account the effect of forests. As such, an accurate assessment of the protective effect of a forest stand can be undertaken. Validation of these models is primarily being done by comparing simulated and mapped deposit positions of previous rockfall events or by comparing simulated rebound heights with mapped tree impact heights. The latter can be mapped directly on the tree stem or by using treering data (Stoffel et al 2006).

The preparation for detailed model simulations are time and labour intensive, as many parameters require precise measurements and mapping campaigns in the field. At the same time, methods to estimate parameter values that determine the elasticity and roughness of slope surface - two very important parameters in rockfall simulation models - are still very subjective and qualitative.

Rockfall simulation models can also be coupled with forest growth simulators (Botkin et al 1972, Shugart 1984, Hasenauer et al 2000, Bugmann 2001, Courbaud et al 2001, Lexer \& Hönninger 2001, Rammig et al 2006). This allows for investigation of the effect of silvicultural interventions on the future protective effect of a forest. As such, they provide solutions for dealing with uncertainties on the effect of silvicultural interventions over long periods of time, and thus address the slow rates of tree regeneration and tree growth of mountain forests. However, over long periods of time these forests may be influenced by the rapid destructive forces such as rockfall, snow avalanches, and windstorms, and, to a certain extent, ungulate browsing. To account for all these disturbances in a simulation model is almost an impossible task. Developing a coupled forest growth rockfall model, that includes the interaction between the biotic and abiotic processes (e.g., increased tree mortality due to rockfall impacts) is already challenging enough. An attempt in this direction is currently being made with the PICUS forest stand development simulation model, as described by Woltjer et al (2007). Attempts to couple forest growth with rapid rockfall assessment tools have been done by Brauner et al (2005) and Wehrli et al (2006). Currently, an attempt is being made to couple Capsis (e.g., Courbaud et al 2001) and Rockfor.net (Berger \& Dorren 2007). To improve coupling of such models, more knowledge is needed on the impact of rockfall on the long term resilience and stability of forest stands; e.g., quantifying the increased mortality in the stand due to rockfall.

Finally, simulation models can be used as decision-support tools. For example, if thinning is to be carried out to promote regeneration, the protective effect is likely decreased locally and temporary. In such a case, the application of an accurate, spatially explicit rockfall model allows determining the 
intensity of the intervention to prevent a significant increase in the residual rockfall hazard (i.e., number of rocks travelling through the forest).

\section{Management of rockfall protection forests}

Target values of stand parameters for effective protection have been established since the 1990's (Chauvin et al 1994, Wasser \& Frehner 1996). In the minimal tending guidelines for managing rockfall forests developed by Wasser \& Frehner (1996), the proposed stand density is independent of the size and energy of the falling rock (400 trees/ha). The minimal tending guidelines aim at optimising protective effects of forests with as little intervention as possible. Based on the real-size experiments, Dorren et al (2005) concluded that the number of impacts against trees were generally more important than the efficacy of a single impact expressed in the amount of energy dissipated by a single tree. For example, it is known from experience that coppice stands can be very effective in stopping small rocks (Gerber \& Elsener 1998). Coppice stands have trees reproduced vegetatively from stumps or from suckering by roots. They grow faster than seedlings because they have complete root systems. Therefore, they produce «instant» and usually dense regeneration. The optimal combination of stand density and mean DBH, however, depends on the size and energy of the falling rock. Currently, the notion of rock-size dependent forest stand management has been integrated in new guidelines (Frehner et al 2005, Gauquelin et al 2006). These guidelines also provide values for maximal distances between trees in the fall direction. A limit of $20-40 \mathrm{~m}$ is often mentioned because, after falling $40 \mathrm{~m}$ down a slope without impacting trees, rocks can gain sufficient energy to destroy trees (Gsteiger 1993, Wasser \& Frehner 1996, Dorren et al 2005, Gauquelin et al 2006).

In addition to the characteristics of the falling rocks and the characteristics of the stand itself, the protective effect of a forest also depends on terrain characteristics. Terrain characteristics known to significantly influence rockfall events significantly include: 1) slope angle, 2) surface roughness (structural features that influence the velocity of falling rocks, e.g., rocks and logs, and 3) surface damping (ground or soil characteristics that determine the amount of energy absorbed). Forest management can influence terrain characteristics in many ways.

The management of protection forests is to a large degree a trade-off between optimising the protective effect and assuring forest stand stability at present and over the long term (Dorren et al 2004).
Since stand stability is mostly at risk in over-mature stands that lack sufficient regeneration, management interventions in rockfall protection forests often aim at thinning or creating gaps to allow more light into the forest stand. To increase terrain roughness, a common recommendation in rockfall protection forest management is to leave the trunks of cut trees lying on the slope (Figure 9), preferably diagonally to the slope direction, to create obstacles (Mössmer et al 1994, Schwitter 1998, Dorren et al 2005, Frehner et al 2005). These diagonally positioned logs prevent the development of rock accumulations and allow continued rock transport in a controlled manner. The experience in Austria is that larger Picea abies trees $(\mathrm{DBH}>50 \mathrm{~cm})$ can act as effective rockfall barriers for approximately ten years (Dorren et al 2005). A similar increase in terrain roughness was observed in snag stands (Kupferschmid Albisetti et al 2003, Ammann 2006) and on uncleared wind-throw areas (Frey \& Thee 2002, Schönenberger et al 2005). Both latter studies have reported effective protection against rockfall and/or avalanches for 30 years. Additionally, high tree stumps (e.g., > $1.3 \mathrm{~m}$ ) have been noted to further reduce residual rockfall hazard on a site (Dorren et al 2005, Frehner et al 2005).

Forest roads provide an example of how forest management influences terrain characteristics and, therefore, the rockfall process. Dorren et al (2005) reported that roads stopped $13-15 \%$ of the falling rocks both on forested and non-forested slopes with a gradient of $38^{\circ}$. A similar effect was observed at the Stotzigwald site close to Gurtnellen (Canton Uri, Switzerland) in December 2002, when a large rockslide was stopped on a forest-road, leaving a crater approximately $1 \mathrm{~m}$ deep. ${ }^{2}$ Another example was observed in 2004 at the Gschösswand in the Zillertal (Austria) as shown in Figure 10.

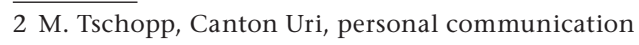

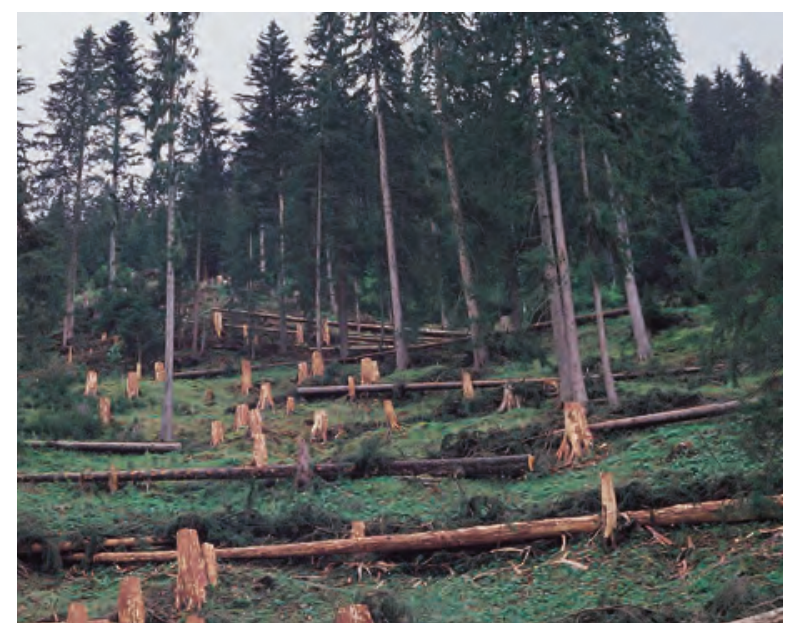

Fig 9 Rockfall protection by obstacles consisting of logs positioned on the slope (Photo: Bernhard Maier). 


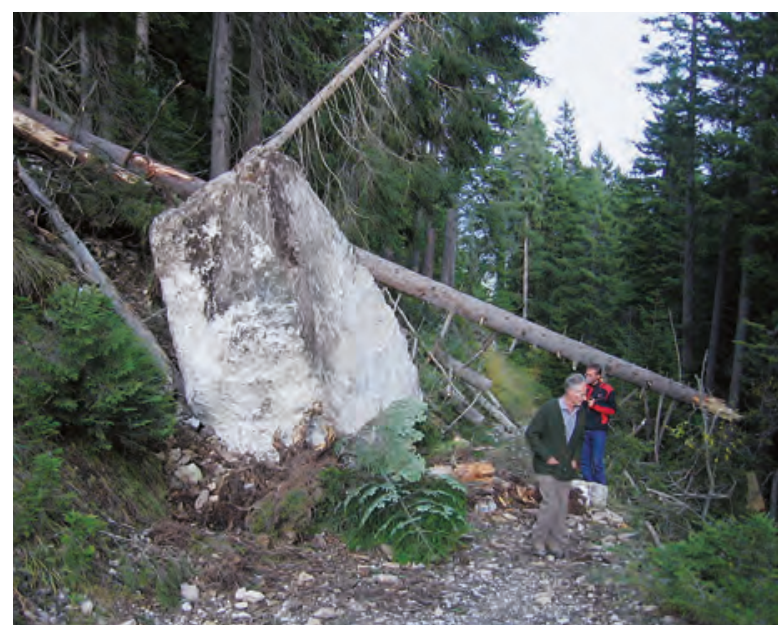

Fig 10 Rock stopped on a forest road at the Gschösswand in the Zillertal in Austria.

\section{Future challenges}

One of the major future challenges in the rockfall source area is developing methods to predict when and what rock (type and size) will fall. Monitoring devices such as the terrestrial laser scanner, crack-meters or extensometers provide good opportunities for this, but methods have to be further developed. In the transit and deposit area the major challenge is to quantify the effect of different slope surfaces on the energy dissipation during a rockfall rebound and to develop objective methods for characterising the elasticity and roughness of different surface types. With respect to forest rockfall research we identified multiple challenges. The most important are:

- Obtaining knowledge on the behaviour of the root systems of trees during rock impacts as, until now, no approach exists for modelling the highly dynamic behaviour of the root-soil system during a rockfall impact.

- Obtaining quantitative information about the relationship between energy absorption capacity and DBH for multiple tree species, as well as information on how the energy absorption capacity decreases with increasing impact height on the tree stem.

- Studying the effect of the impact eccentricity, taking into account the kinetic energy of the rock, its shape and size as well as the height of the impacts using 3D information of the rock velocity.

- Gaining knowledge on the role of coppice stands in rockfall protection (energy dissipation, regeneration, etc.). The initial focus should be to determine how much energy can be absorbed by collectives of sprouts with small diameters in relation to the density and age of the coppiced trees. Rocks are sometimes trapped between branches as branches are highly flexible and therefore present different protection mechanisms than adult single trees.
Obtaining a relationship between tree mortality and bark or tree wounds due to rock impacts and understanding mechanisms of the effects of rock impacts on mortality.

- Studying the relationship between the structural integrity or soundness of the wood (phytosanitary state) of trees and roots and their energy dissipative capacity.

- Studying the long-term effect of rockfall on the protective effect of forest stands taking into account silvicultural measures such as thinning, prevention of ungulate browsing and leaving tree trunks diagonally on the slope. This can be done by coupling rockfall and forest growth simulators, but should include field trials.

- Developing and validating easy-to-use tools for zoning the rockfall hazard in 2D with and without accounting for the effect of forests.

- Studying the effect of different forest stand structures and compositions on the protective capacity of a stand.

- Using laser scanning data for improving the digital terrain models used by rockfall simulation models and for characterising forest stand structures (stand density, spatial distribution of trees and diameter distribution derived from laser scanning data).

- Undertaking cost-benefit studies for rockfall protection using technical protective measures, protection forests or a combination of the two.

- Establishing monitoring, documentation and archiving systems for rockfall events to document and gain from the experience of practitioners in the field.

- Undertaking additional real-size rockfall experiments on sites with different terrain and forest characteristics.

\section{Conclusions}

At present, it is difficult to provide probabilities that unstable rocks will actually fall as a function of a given time period. However, currently available methods allow us to assess the frequency of historical rockfall events and the distribution of the size of the falling rocks. The latter is very important since it determines the energy of the falling rock and the tree impact probability. As such, it also determines the optimal stand structure as well as the required mean tree diameter to dissipate the energy of the falling rock. Scientific research has recently provided basic relationships to determine stand structural parameters. There are, however, many remaining research challenges to improve our knowledge of these relationships. Regarding practical aspects of rockfall protection forest management, detailed guidelines currently exist and evolve con- 
stantly as new scientific knowledge becomes available. This process should be continued, but there is also a need for the development of easy-to-use tools for zoning the rockfall hazard in 2D with and without accounting for the effect of forests.

\section{Acknowledgement}

We thank Manfred Lexer and David Wilford for their valuable suggestions and comments, and Lakhdar Bengrine for his assistance during the final phase of the article.

\section{References}

ABELE G (1972) Kinematik und Morphologie spät- und postglazialer Bergstürze in den Alpen. Z Geomorph NF Suppl 14: 138-149.

ALLABY A, ALLABY M (1990) Oxford concise dictionary of earth sciences. New York: Oxford Univ Press. 410 p.

AMMANN M (2006) Schutzwirkung abgestorbener Bäume gegen Naturgefahren. Zürich: Eidg Techn Hochschule, PhD Thesis. $188 \mathrm{p}$.

AZZONI A, DE FREITAS MH (1995) Experimentally gained parameters decisive for rock fall analysis. Rock Mech Rock Eng 28 (2): 111-124.

BAJGIER-KOWALSKA M (2002) The application of lichenometry in the dating of landslide-rockfall slopes in the Beskid Zywiecki Mountains (Flysh Carpathians). Czasop Geogr 73: $215-230$.

BAKKER JP, LE HEUX JWN (1946) Projective-geometric treatment of O. Lehmann's theory of the transformation of steep mountain slopes. Proc K Ned Akad B-PH 49: 533-547.

BALLANTYNE CK, STONE JO (2004) The Beinn Alligin rock avalanche, NW Scotland: cosmogenic 10Be dating, interpretation and significance. Holocene 14: 448-453.

BARTON N, EDITOR (1978) Suggested methods for the quantitative description of discontinuities in rock masses. Int J Rock Mech Min Sc Geomech Abstr 15: 319-368.

BERGER F, DORREN LKA (2007) Principles of the tool Rockfor.net for quantifying the rockfall hazard below a protection forest. Schweiz Z Forstwes 158: 157-165. doi:10.3188/ szf.2007.0157

BLAIR TC, MCPHERSON JG (1999) Grain-size and textural classification of coarse sedimentary particles. J Sediment Res 69 (1): 6-19.

BOTKIN DB, JANAK JF, WALLIS JR (1972) Some ecological consequences of a computer model of forest growth. J Ecol 60: 849-872.

BOZZOLO D, PAMINI R (1986) Simulation of rock falls down a valley side. Acta Mech 63: 113-130.

BRAUNER M, WEINMEISTER W, AGNER P, VOSPERNIK S, HOESLE B (2005) Forest management decision support for evaluating forest protection effects against rockfall. For Ecol Manage 207: 75-85.

BROILLI L (1974) Ein Felssturz in Grossversuch. Rock Mech Suppl 3: 69-78.

BUDETTA P (2004) Assessment of rockfall risk along roads. Nat Hazards Earth Sys 4: 71-81.

BUGMANN H (2001) A review of forest gap models. Clim Chang 51: 259-305.
BULL WB, BRANDON MT (1998) Lichen dating of earthquakegenerated regional rockfall events, Southern Alps, New Zealand. Bull Geol Soc Am 110 (1): 60-84.

CATTIAU V, MARI E, RENAUD JP (1995) Forêt et protection contre les chutes de rochers. Ingéneries EAI 3: 45-54.

CHAU KT, WONG RHC, WU JJ (2002) Coefficient of restitution and rotational motions of rockfall impacts. Int J Rock Mech Min Sci 39 (1): 69-77.

CHAUVIN C, RENAUD JP, RUPÉ C (1994) Stabilité et gestion des forêts de protection. ONF Bull Techn 27: 37-52.

COROMINAS J ET AL (2005) Quantitative assessment of the residual risk in a rockfall protected area. Landslides 2: 343-357.

COURBAUD B, GOREAUD F, DREYFUS P, BONNET FR (2001) Evaluating thinning strategies using a tree distance dependent growth model: some examples based on the CAPSIS software «uneven-aged spruce forests» module. For Ecol Manage 145: 15-28.

COUVREUR S (1982) Les forêts de protection contre les risques naturels. Nancy: École Nationale du Génie Rural des Eaux et Forêts. 89 p.

CRANDELL DR, FAHNESTOCK RK (1964) Rock falls and avalanches, Little Tahoma Peak, Mt. Rainier, Washington. Bull US Geol Surv 1221(A): 1-30.

DESILETS D, ZREDA M, ALMASI PF, ELMORE D (2006) Determination of cosmogenic $36 \mathrm{Cl}$ in rocks by isotope dilution: innovations, validation and error propagation. Chem Geol 233: 185-195.

DOCHE O (1997) Etude expérimentale de chutes de blocs en forêt. Grenoble: Cemagref, doc 97/0898. 130 p.

DORREN LKA (2003) A review of rockfall mechanics and modelling approaches. Progr Phys Geog 26: 69-87.

DORREN LKA, BERGER F (2006) Stem breakage of trees and energy dissipation at rockfall impacts. Tree Physiol 26: 63-71.

DORREN LKA, BERGER F, LE HIR C, MERMIN E, TARDIF P (2005) Mechanisms, effects and management implications of rockfall in forests. For Ecol Manage 215: 183-195.

DORREN LKA, BERGER F, PUTTERS US (2006) Real size experiments and 3D simulation of rockfall on forest slopes. Nat Hazards Earth Syst 6: 145-153.

DORREN LKA, BERGER F, IMESON AC, MAIER B, REY F (2004) Integrity, stability and management of protection forests in the European Alps. For Ecol Manage 195: 165-176.

DORREN LKA, SEIJMONSBERGEN AC (2003) Comparison of three GIS-based models for predicting rockfall runout zones at a regional scale. Geomorphology 56 (1-2): 49-64.

DUSSAUGE-PEISSER C ET AL (2002) Probabilistic approach to rock fall hazard assessment: potential of historical data analysis. Nat Hazards Earth Syst 2: 15-26.

ERISMANN TH, ABELE G (2001) Dynamics of rockslides and rockfalls. Berlin: Springer. 316 p.

FEHR R (1987) Einfache Bestimmung der Korngrößenverteilung von Geschiebematerial mit Hilfe der Linienzahlanalyse. Schweiz Ing Archit 138: 1104-1109.

FOETZKI A ET AL (2004) Die mechanische Stabilität von Bäumen: das Projekt Baumstabilität des FB Naturgefahren. Birmensdorf: Eidgenöss Forsch.anst Wald Schnee Landsch, Forum für Wissen. pp. 35-42.

FREHNER M, WASSER B, SCHWITTER R (2005) Nachhaltigkeit und Erfolgskontrolle im Schutzwald - Wegleitung für Pflegemassnahmen in Wäldern mit Schutzfunktion. Bern: Bundesamt Umwelt Wald Landschaft. 564 p.

FREY W, THEE P (2002) Avalanche protection of windthrow areas: A ten year comparison of cleared and uncleared starting zones. For Snow Landsc Res 77 (1-2): 89-107. 
FRIEDEL H (1935) Beobachtungen an den Schutthalden der Karawanken. Carinthia II 125 (45): 21-33.

GARDNER J (1970) Rockfall: A geomorphic process in high mountain terrain. Albertan Geogr 6: 15-20.

GAUQUELIN X ET AL (2006) Guide des sylvicultures de montagne. Grenoble: Cemagref. 289 p.

GERBER E (1974) Klassifikation von Schutthalden. Geogr Helv 29: 73-82.

GERBER C, ELSENER O (1998) Niederwaldbetrieb im Steinschlaggebiet. Wald Holz 79 (14): 8-11.

GERBER W (1998) Waldwirkung und Steinschlag. In: Proc 14. Arbeitstagung Schweizerischen Gebirgswaldpflegegruppe \& FAN, Grafenort/Engelberg, unpublished report. pp. 1-15.

GERBER W (2001) Guideline for the approval of rockfall protection kits. Bern: Swiss Agency Environment Forests Landscape, Environment in Practice. 39 p.

GIANI GP (1992) Rock slope stability analysis. Rotterdam: Balkema. 361 p.

GLADE T, LANG M, EDITORS (2003) Strategies and applications in natural hazard research using historical data. Nat Hazards 31 (3). 99 p.

GOODMAN RE, SHI GH (1985) Block theory and its application to rock engineering. London: Prentice-Hall. $338 \mathrm{p}$.

GSTEIGER P (1993) Steinschlagschutzwald. Ein Beitrag zur Abgrenzung, Beurteilung und Bewirtschaftung. Schweiz Z Forstwes 144: 115-132.

GUZZETTI F, CROSTA G, DETTI R, AGLIARDI F, (2002) STONE: a computer program for the three-dimensional simulation of rock-falls. Comp Geosci 28: 1079-1093.

HANTZ D, VENGEON JM, DUSSAUGE-PEISSER C (2003) An historical, geomechanical and probabilistic approach to rock-fall hazard assessment. Nat Hazards Earth Syst 3: 693-701.

HASENAUER H, BURGMANN M, LEXER MJ (2000) Konzepte der Waldökosystemmodellierung. Cent.bl gesamte Forstwes 117: 137-164.

HOEK E, BRAY JW (1981) Rock Slope Engineering. London: Institution Mining Metallurgy. $402 \mathrm{p}$.

HUNGR O, EVANS SG (1988) Engineering evaluation of fragmental rockfall hazards. In: Proc 5th Int Symp Landslides, Lausanne (10-15 Jul 1988). Rotterdam: Balkema. pp. 685-690.

JABOYEDOFF M, DUDT JP, LABIOUSE V (2005) An attempt to refine rockfall hazard zoning based on the kinetic energy, frequency and fragmentation degree. Nat Hazards Earth Syst 5: 621-632.

JAHN J (1988) Entwaldung und Steinschlag. In: Proc Interpraevent, Graz, vol 1. pp. 185-198.

KENT PE (1966) The transport mechanism in catastrophic rockfalls. J Geol 74: 79-83.

KALBERER M, AMMANN M, JONSSON M (2007) Mechanische Eigenschaften der Fichte: Experimente zur Analyse von Naturgefahren. Schweiz Z Forstwes 158 166-175 doi: 10.3188/szf.2007.0166

KIRKBY MJ, STATHAM I (1975) Surface stone movement and scree formation. J Geol 83: 349-62.

KRAUTBLATTER M, DIKAU R (2007) Towards a uniform concept for the comparison and extrapolation of rockwall retreat and rockfall supply. Geogr Ann 89A: 1-20.

KRAUTBLATTER M, MOSER M (2006) Will we face an increase in hazardous secondary rockfall events in response to global warming in the foreseeable future? In: Price MF, editor. Global Change in Mountain Regions. Duncow: Sapiens. pp. 253-254.

KRAUTBLATTER M, MOSER M, SCHROTT L, WOLF J (2007) A study on sediment yield and geomorphic work comprising all rockfall magnitudes in an Alpine Catchment (Reintal, German Alps). Geomorphology (in press).

KUPFERSCHMID ALBISETTI AD, BRANG P, SCHOENENBERGER W, BUGMANN H (2003) Decay of Picea abies snag stands on steep mountain slopes. For Chron 79: 247-252.

LANG A, MOYA J, COROMINAS J, SCHROTT L, DIKAU R (1999) Classic and new dating methods for assessing the temporal occurrence of mass movements. Geomorphology 30: 33-52.

LE HIR C (2005) Forêt et chutes de blocs: méthodologie de modélisation spatialisée du rôle de protection. Marne-LaVallée: Univ Marne-La-Vallée, PhD Thesis. 195 p.

LEHMANN O (1933) Morphologische Theorie der Verwitterung von Steinschlagwänden. Vierteljahrschr Nat.forsch Ges Zür 87: 83-126.

LEXER MJ, HÖNNINGER K (2001) A modified 3D-patch model for spatially explicit simulation of vegetation composition in heterogeneous landscapes. For Ecol Manage 144: 43-65.

LINIGER M (2000) Computersimulation von Stein- und Blockschlägen. Felsbau 18 (3): 64-68.

MAZZOCCOLA DF, HUDSON, JA (1996) A comprehensive method of rock mass characterization for indicating natural slope instability, Quart J Engin Geol 29: 37-56.

MCCARROLL D, SHAKESBY RA, MATTHEWS IS (1998) Spatial and temporal patterns of Late Holocene rockfall activity on a Norwegian talus slope: lichenometry and simulation-modelling approach. Arct Alp Res 30: 51-60.

MEISSL G (2001) Modelling the runout distances of rockfall using a geographic information system. Z Geomorphol NF Suppl 125: 129-137.

MÖLK M (2000) The Kreuzlau rockfall - methodical approach for the collection of basic data aiming at the evaluation of rockfall hazards and the planning of counter-measures. Felsbau 18 (1): 47-51.

MORCHE D, KATTERFELD C, FUCHS S, SCHMIDT KH (2006) The life-span of a small high mountain lake, the Vordere Blaue Gumpe in Upper Bavaria, Germany. In: Rowan J, Duck RW, Werritty A, editors. Sediment dynamics and the hydromorphology of fluvial systems. Wallingford: IAHS Press. pp. 72-81.

MÖSSMER EM, AMMER U, KNOKE T (1994) Technisch-biologische Verfahren zur Schutzwaldsanierung in den oberbayrischen Kalkalpen. München: Bayer Landesanstalt Wald Forstwirtschaft, forstl Forsch.ber 145. $135 \mathrm{p}$.

O'HARA KL (2006) Multiaged forest stands for protection forests: concepts and applications. For Snow Landsc Res 80 (1): 45-56.

OMURA H, MARUMO Y (1988) An experimental study of the fence effects of protection forests on the interception of shallow mass movement. Mitt Forstl Bundesvers.anst Mariabrunn Wien 159: 139-147.

PEILA D, PELIZZA S, SASSUDELLI F (1998) Evaluation of behaviour of rockfall restraining nets by full scale tests. Rock Mech Rock Eng 31 (1): 1-24.

PERRET S, DOLF F, KIENHOLZ H (2004) Rockfalls into forests: Analysis and simulation of rockfall trajectories - considerations with respect to mountainous forests in Switzerland. Landslides 1: 123-130.

PERRET S, STOFFEL M, KIENHOLZ H (2006) Spatial and temporal rockfall activity in a forest stand in the Swiss Prealps a dendrogeomorphological case study. Geomorphology 74: 219-231.

PIERSON LA, DAVIS SA, VAN VICKLE R (1990) Rockfall hazard rating system. Implementation Manual. Washington DC: Federal Highway Administration, US Dep Transp, Report FHWA-OR-EG-90-01. 
PRIEST SD, HUDSON JA (1976) Discontinuity spacings in rock. Int J Rock Mech Min Sc Geomech Abstr 13: 135-148.

RAMMIG A, FAHSE L BUGMANN H, BEBI P (2006) Forest regeneration after disturbance: a modelling study for the Swiss Alps. For Ecol Manage 222: 123-136.

RICKLI C, GRAF F, GERBER W, FREI M, BÖLL A (2004) Der Wald und seine Bedeutung bei Naturgefahren geologischen Ursprungs. Birmensdorf: Eidgenöss Forsch.anst Wald Schnee Landsch, Forum für Wissen. pp. 27-34.

ROMANA M (1988) Practice of SMR classification for slope appraisal. In: Proc 5th Int Symp Landslides, Lausanne (1015 Jul 1988). Rotterdam: Balkema. pp. 1227-1229.

ROUILLER JD, JABOYEDOFF M, MARRO C, PHLIPPOSSIAN F (1997) Matterock: méthodologie d'étude d'instabilités de falaise et d'appréciation du danger. Publ Soc Suisse Méc Sols Roches 135: 13-16.

SASS O (2005) Spatial patterns of rockfall intensity in the northern Alps. Z Geomorphol NF Suppl 138: 51-65.

SASS O, KRAUTBLATTER M (2007) Debris-flow-dominated and rockfall-dominated scree slopes: genetic models and process rates derived from GPR measurements. Geomorphology 86: 176-192. doi:10.1016/j.geomorph.2006.08.012

SCHEIKL M (2006) Risk assessment of the rockslide Spitz (Austria) based on laser scanner date, stability calculations and run-out models. In: Proc 3rd Colloquium Rock Mechanics - Theory and Practice, Vienna (Mar 2006). Vienna: Vienna University of Technology.

SCHÖNENBERGER S, NOACK A, THEE P (2005) Effect of timber removal from windthrow slopes on the risk of snow avalanches and rockfall. For Ecol Manage 213: 197-208.

SCHROTT L, NIEDERHEIDE A, HANKAMMER M, HUFSCHMIDT G, DIKAU R (2002) Sediment storage in a mountain catchment: geomorphic coupling and temporal variability (Reintal, Bavarian Alps, Germany). Z Geomorphol NF Suppl 127: 175-196.

SCHWITTER R (1998) Zusammenfassung und Schlussfolgerungen. In: Proc 14. Arbeitstagung Schweizerischen Gebirgswaldpflegegruppe \& FAN, Grafenort/Engelberg, unpublished report. pp. 1-5.

SHUGART HH (1984) A theory of forest dynamics. The ecological implications of forest succession models. New York: Springer. $278 \mathrm{p}$.

SMEKAL A (1920) Über den im Hochgebirge bei Steinschlag auftretenden Geruch. Naturwissenschaften 8 (25): 496.

\section{Stand des Wissens in den Wechselbeziehun- gen zwischen Steinschlag und Wald}

Um Steinschlagschäden unterhalb von Wäldern zu verhindern, können waldbauliche, ingenieur-biologische, technische oder eine Kombination dieser Massnahmen zum Einsatz kommen. Für eine günstige und wirksame Ausführung ist es wichtig zu wissen, 1) wo und in welcher Grössenordnung Steinschlagereignisse auftreten, 2) um welches Ausmass der Wald die Auslaufdistanz, die Sprunghöhe und die Energie der herunterfallenden Steine oder Felsen verringert und 3) wie die Schutzwirkung des Wald verbessert werden kann. Der Aufsatz gibt einen Überblick über den heutigen Wissensstand und über die in der Praxis verwendeten Methoden. Der Beitrag benennt zudem die wichtigsten Herausforderungen, welche im Rahmen einer umfassenden Steinschlag-Wald-Forschung gelöst werden müssen.
STOFFEL M (2006) A review of studies dealing with tree rings and rockfall activity: The role of dendrogeomorphology in natural hazard research? Nat Hazards 39 (1): 51-70.

STOFFEL M, PERRET S (2006) Reconstructing past rockfall activity with tree rings: some methodological considerations. Dendrochronologia 24 (1): 1-15.

STOFFEL M, LIÈVRE I, MONBARON M, PERRET S (2005B) Seasonal timing of rockfall activity on a forested slope at Täschgufer (Valais, Swiss Alps) - a dendrochronological approach. Z Geomorphol 49 (1): 89-106.

STOFFEL M ET AL (2005A) Analyzing rockfall activity (16002002) in a protection forest - a case study using dendrogeomorphology. Geomorphology 68: 224-241.

STOFFEL M ET AL (2006) Assessing the protective effect of mountain forests against rockfall using a 3D simulation model. For Ecol Manage 225: 113-122.

STOKES A ET AL (2005) Mechanical resistance of different tree species to rockfall in the French Alps. Plant Soil 278: 107-117.

TAYLOR MP, VILES HA (2000) Improving the use of microscopy in the study of weathering: sampling issues. Z Geomorphol NF Suppl 120: 145-158.

TRUDGILL ST, VILES HA (1998) Linking field and laboratory based measurements of limestone weathering rates. Q J Eng Geol 31: 333-341.

WASSER B, FREHNER M (1996) Minimale Pflegemassnahmen für Wälder mit Schutzfunktion. Wegleitung. Bern: Bundesamt Umwelt Wald Landschaft. $122 \mathrm{p}$.

WEHRLI A ET AL (2006) Modelling the long-term impacts of forest dynamics on the protective effect against rockfall. For Snow Landsc Res 80 (1): 57-76.

WENTWORTH CK (1922) A scale of grade and class terms for clastic sediments. J Geol 30: 377-392.

WHALLEY WB (1984) Rockfalls. In: Brundsden D, Prior DB, editors. Slope instability. London: Wiley. pp. 217-256.

WINCHESTER V, CHAUJAR RK (2002) Lichenometric dating of slope movements in the Nant Francon, North Wales. Geomorphology 47: 61-74.

WOLTJER M ET AL (2007) Coupling a 3D patch model and a rockfall module to assess rockfall protection in mountain forests. J Env Manage. in press. doi:10.1016/j.jenvman. 2007.01.301

ZINGGELER A (1990) Steinschlagsimulation in Gebirgswäldern: Modellierung der relevanten Teilprozesse. Bern: Univ Bern, MSc Thesis. 116 p.

\section{État des connaissances sur les interactions entre les chutes de pierres et la forêt}

Pour prévenir les chutes de pierres à l'aval des forêts, on peut utiliser la gestion forestière, l'ingénierie écologique ou civile, ou une combinaison de celles-ci. Pour une réalisation peu coûteuse et efficace, il faut savoir 1) où et dans quelle ampleur se produisent les chutes de pierres, 2) dans quelle mesure la forêt réduit la distance d'arrêt, la hauteur de rebond et l'énergie des pierres et des blocs en chute, et 3) comment l'effet protecteur de la forêt peut être amélioré. L'article fournit un aperçu de l'état actuel des connaissances et des méthodes utilisées dans la pratique. II mentionne en outre les principales exigences à respecter dans le cadre d'une vaste étude sur les chutes de pierres et la forêt. 